\author{
AMERICAN JOURNAL OF FOOD AND NUTRITION \\ Print: ISSN 2157-0167, Online: ISSN 2157-1317, doi:10.5251/ajfn.2011.1.4.155.165 \\ (c) 2011, ScienceHuß, http://www.scihub.org/AJFN
}

\title{
Potential of Aframomum danielli spice powder in reducing ochratoxin A in cocoa powder
}

\author{
${ }^{1}$ Aroyeun S.O., ${ }^{2}$ Adegoke G.O. ${ }^{3}$ Varga J., ${ }^{4}$ Teren J., ${ }^{3}$ Karolyi P., \\ ${ }^{3}$ Kuscbe $\mathrm{S}$. and ${ }^{3}$ Valgvolgyi C.
}

\author{
${ }^{1}$ Cocoa Research Institute of Nigeria, Ibadan, P.M.B. 5244, Ibadan Oyo State Nigeria. \\ ${ }^{2}$ University of Ibadan, Faculty of Technology, Department of Food Technology \\ ${ }^{3}$ Department of Microbiology, Faculty of Science, University of Szeged, P.O. Box 533, H- \\ 6701, Szeged, Hungary. \\ ${ }^{4}$ Animal Health and Food Control Station, P.O. Box 446, H-6701, Szeged, Hungary. \\ Corresponding author email: aroyeun2000@yahoo.co.uk; Tel: +234-805-915-
} 879-5

\begin{abstract}
Eighty-five cocoa powder samples were screened for ochratoxin A (OTA) from different warehouses in the southwestern part of Nigeria. Samples containing greater than $2 \mathrm{ng} / \mathrm{g}$ of OTA were treated with powder of Aframomum danielli at 0 ppm, 40000ppm, 60,000ppm and 80,00ppm of the powder $(\mathrm{w} / \mathrm{w})$. The treated samples were later assessed for OTA using high performance liquid chromatography with fluorescent detector and enzyme linked immunosorbent assay. The effect of the spice powder was evaluated for proximate analysis to determine the nutrient retention value. Sensory evaluation of the cocoa beverage prepared from the treated cocoa powder was carried out using trained taste panelists. This study established the presence of OTA in $71.7 \%$ of all samples examined. OTA contamination varied from warehouse to warehouse. In all the warehouses, OTA of $0.15-0.50 \mathrm{ng} / \mathrm{g}$ was the commonest followed by $0.51-1.6 \mathrm{ng} / \mathrm{g}$. Only four out of five samples from Lagos had $>2 \mathrm{ng} / \mathrm{g}$ OTA.. Treating cocoa powder with A.danielli spice powder resulted in $15 \%$ reduction of OTA at $40,000 \mathrm{ppm}$ and at $80,000 \mathrm{ppm}$, it further reduced the OTA to $1.86 \mathrm{ng} / \mathrm{g}$. There was a reduction in the formation of OTA at all treatment of cocoa powder in comparison with the control samples without the spice treatment. The effect of the addition of A.danielli spice powder caused more than $100 \%$ nutrient retention value on the cocoa powder Increase in the spice powder addition resulted in a significant increase in protein, ash and minerals like potassium, calcium and magnesium when compared to untreated control. Sensory analysis carried out revealed significant differences among A..danielli treated cocoa powder and untreated samples in taste, odour, flavour and overall acceptability. At $80,000 \mathrm{ppm}$ of the spice powder treatment, the taste became bitter, colour became duller and general acceptability became lower...In conclusion, A.danielli spice powder can be used as a biopreservative in cocoa powder contaminated with ochratoxin $A$ at maximum concentrations of $60,000 \mathrm{ppm}$ above which the sensory quality decreased.
\end{abstract}

Keywords: Aframomum danielli, ELISA; cocoa powder, reduction, ochratoxin A

\section{INTRODUCTION}

Ochratoxin A (OTA) is highly nephrotoxic, causing both acute and chronic lesions of kidneys and has been suspected to be involved in the aetiology of Balkhan Endemic Nephropathy, a disease characterized by progressive renal fibrosis in humans and its implication in the urinary tract tumours (IARC, 1993). OTA is recognized as a potent teratogen in mice, rats, hamsters and chickens and it is known to affect the immune system in a number of mammalian species

Cocoa powder is one of the major products obtained from post harvest processing of cocoa beans (Theobroma cacao, L). it is consumed as beverage at various homes as breakfast foods or taken as cold or iced cocoa beverage drinks in tropical Nigeria during dry season. (Aroyeun et al, 2006). Many other consuming foreign countries also utilized cocoa 
powder in the fortification of other confectionery products like cake, ice cream, biscuit, bread and so on. Many reports have identified poor storage condition as factors that favour mould growth in cocoa powder and subsequent production of toxic secondary fungal metabolites (Mycotoxin). Relative humidity and high ambient temperature facilitate fungal growth and hence dietary exposures to high levels of mycotoxin in this food is highly inevitable. (Ogunbanwo, 2005). Apart from the aforementioned, the hygroscopic nature of cocoa powder will result in absorption of moisture from the environment which will favour mould growth. Some authors have revealed ochratoxin A contamination in cocoa beans, cocoa powder and other cocoa related products (Bonvehi, 2004; Tafuri et al., 2004; Aroyeun and Adegoke. 2006; Aroyeun et al., 2007; Aroyeun et al., 2009a, Aroyeun et al., 2009b). Ochratoxin A has been reported in cocoa powder in Ivory Coast, Guinea, Nigeria and Cameroon up to $4.4 \mathrm{ng} / \mathrm{kg}$. Tafuri et al. (2004) established that about $22 \%$ of cocoa powder sold in Italian shops contained OTA. About $1800 \mathrm{ng} / \mathrm{kg}$ OTA has been found in German cocoa powder between 1996 - 1999. European Union (EU) has established a regulatory limit of $2 \mathrm{ng} / \mathrm{g}$ OTA for all cocoa and cocoa products to safe consumers of this toxic metabolite.

As a result of the health implication of this toxic metabolite (OTA), the focus of research after detection is reduction of the toxin to a level equal to or lower than the EU regulatory limit established at 2 $\mathrm{ng} / \mathrm{g}$. This attempt will not only enhance trade but will give a good image to the source of the cocoa powder and majorly protect consumers from the toxic nature of OTA. As a means of detoxifying contaminated food and feed by

microorganisms, several methods have been developed. Nevertheless, only a few of them (e.g. destruction by ammonia treatment) have been accepted for practical use. Many specialists are of the opinion that the best approach for decontamination should be degradation by selected microorganisms. Considerable interest has developed during recent years on the preservation of grains by the use of spice essential oils or spice powder to effectively retard growth and mycotoxin production (Bullerman et al, 1977).

The code of practice for the prevention and reduction of ochratoxin A in cocoa and cocoa powder from Nigeria was a request of the European community in view of the danger it poses on human and livestock Many other reports are available on the use of spice essential oils, aqueous extracts and powdered extracts in the reduction of fungal capable of producing mycotoxin : Aflatoxin $\mathrm{B}_{1}$, Ochratoxin $\mathrm{A}$, Patulin, Zearalenone, Fumonisin and Deoxynivalenol (Adegoke et al, 2000, Adegoke and Skura, 1994, Atanda et al., 2007 Notable among spices that have been successfully used in this regard are Anise, Caraway, Fennel in the family Umbelliferae; Thyme, Spearmint and Basil in Labiateae family; Chamomile, Marigold, Hazanbul and Qyssum in the family Compositeae; Ghafath in the Rosaceae and Cinnammon in the Lauraceae family (Solimaan and Badeaa, 2002) and Aframomum danielli in the Zingiberaceae family (Adegoke et al. 2002). All these spices and some other more not mentioned have a wide antimicrobial spectrum and antifungal characteristics against pathogens. Furthermore, biologically active natural compounds are of interest to the pharmaceutical industry for the control of human diseases of microbial origin (Neda et al, 2004). It is encouraging that attention is continuously being focused on the use of plant products as alternatives to synthetic additives particularly as consumers are increasingly concerned about synthetic additives. Aframomum danielli, (Hook, F) K. Schum (family, Zingiberaceae) is a large, robust perennial plant $3-4 \mathrm{~m}$ tall which grows in central and west African countries (Adegoke et al, 2000b). The seeds of this plant are used for flavouring traditional dishes and the essential oil is used in perfumery, flavouring and dye preparations. The monoterpenes of the essential oil of $A$. danielli have been used against food spoilage, yeasts and mycotoxin producing mould. (Adegoke et al, 2000a).

Because the literature is replete on reduction of OTA in cocoa powder using the spice A.danielli powder, this study was designed with the aim of testing the potential of A.danielli in the reduction of OTA in cocoa powder, determining the sensory profiles of the treated samples and the nutrient retention values.

\section{MATERIALS AND METHODS}

\section{Procurement of raw materials:}

Aframomum danielli pods were obtained from a Nigerian market. The pods were broken open to release the seeds, which were dried under room temperature before milling. The seeds were milled to separate the seed coat and the endosperm. The seeds were later extracted with $\mathrm{n}$-Hexane to obtain the essential oil, using soxhlet extraction. The residues after extraction were further air-dried at room temperature and reserved for use after milling. 
Eighty-five samples of Cocoa powder were obtained from different processing companies in Isolo, Apapa, Mushin, Ibadan, Oshodi, Ondo, Itire all from the southwest Nigeria and analyzed for ochratoxin A. Thereafter, samples with OTA content of $2 \mathrm{ng} / \mathrm{g}$ and above were further treated with the spice A.danielli.powder to determine the effect of the spice powder on OTA reduction. The choice of the use of the spice powder was made due to its compatibility to the colour of cocoa powder.

Treatment of cocoa powder with the powder of the spice A.danielli. Before treatments with the spice, the initial \%Protein, \%Fat, \%Moisture Contents and $\%$ Ash, were determined according to AOAC (2000). Subsequently, the cocoa powder was treated at $0,40,000 \mathrm{ppm}, 60,000 \mathrm{ppm}$ and $80,000 \mathrm{ppm}$ of $A$. danielli spice powder $(\mathrm{w} / \mathrm{w})$. The treated powder was later introduced into polythene bag on laboratory bench at $28 \pm 30^{\circ} \mathrm{C}$ temperature. Samples were allowed to equilibrate with the spice for 1 hour at each treatment. Thereafter, the proximate composition of the treated samples were done in order to determine nutrient retention value due to treatment using Wagner, (1977) methods..

Isolation of Moulds: Isolation of moulds was done on Dichloran Rose Bengal Chloramphenicol (DRBC) Medium according to (Pitt and Hocking, 1997). All plates were incubated in darkness for 7 days at $20^{\circ} \mathrm{C}$. The numbers of colonies were counted and reported as colony-forming units (CFU) per gram of samples.

\section{Enzyme Linked Immunosorbent Assay (ELISA)}

$1 \mathrm{~g}$ sample of treated and non-treated cocoa powder was transferred into a $50 \mathrm{ml}$ Erlenmeyer flask. Thereafter, $10 \mathrm{ml}$ of dichloromethane and $5 \mathrm{ml}$ of 1 Mcitric acid were added to the flask and the sample was vortexed mixed for 5 minutes, sealed with parafilm, and agitated for 2 hours at RT (about $25^{\circ} \mathrm{C}$ ) on a horizontal shaker. The whole suspension was then transferred to a centrifuge tube and centrifuged for 30 minutes at $4500 \mathrm{~g}$. Three phases, aqueous (upper), sample cake (middle) and dichloromethane (lower), were obtained after centrifugation. The upper aqueous phase was discarded, the sample cake was cut through, and $2 \mathrm{ml}$ of the dichloromethane phase was transferred to another conical tube. Two milliliters of $1 \%$ sodium trioxocarbonate IV buffer was added to this, sealed with parafilm, and shaken for 30 minutes, during which time OTA was transferred into the aqueous solution. The mixture was centrifuged (20 minutes at $4500 \mathrm{~g}$ ) to obtain a clear buffer solution. Four hundred and ninety microlitres of the upper buffer solution was pipetted into a test tube and $10 \mu \mathrm{L}$ of $1 \mathrm{~N} \mathrm{HCl}$ added. The sample was mixed thoroughly and $50 \mu \mathrm{l}$ of this solution was used directly in the ELISA according to (Teren et al, 1996). The colour reaction on microwells was terminated by adding $50 \mu \mathrm{L}$ of $6 \mathrm{~N}$ sulphuric acid and OD450nm was measured with an automated microplate reader (Labsystems Multiscan PLUS, Finland). The standard curve of OTA was obtained by plotting log 10 concentration ( $\mathrm{x}$-axis) against $\mathrm{B} / \mathrm{B}_{\mathrm{o}}$ (y-axis).

blank)

$B / B_{0}=(O D$ of standard or sample $) /(O D$ of

where Optical Density (OD) is the mean

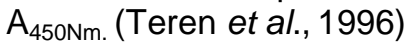

The ochratoxin A concentration in sample extracts was calculated using the calibration curve and was expressed in $\mathrm{ng} / \mathrm{g}$.

\section{HPLC Analysis}

The chloroform extracts of treated and untreated cocoa powder were evaporated and ochratoxin A was redissolved in appropriate amounts of the mobile phase $\left(57 \%\right.$ acetonitriles, $41 \%, \mathrm{H}_{2} \mathrm{O}, 2 \%$ acetic acid and detected on a, HPLC isocratic system with $\mathrm{C}_{18}$ column (Microsorb MY, VARIAN, $250 \times 4 . b m m, 5 \mu l$ particle size) and a fluorescence detector (excitation $330 \mathrm{~nm}$, emission $460 \mathrm{~nm}$ ), with a loop of $50 \mu \mathrm{l}$. The mobile phase was pumped at $1 \mathrm{ml} / \mathrm{min}$. Extracts were considered positive if they yielded a peak at a retention time identical to that of standard OTA. The standard solution was prepared as described by AOAC (2000) using OTA obtained from sigma chemical Co. (St. Louis, MO. USA).

\section{Colour Intensity and Colour Taint of Cocoa Beverage}

Known weight of cocoa powder was dissolved in known volume of water. About $3 \mathrm{ml}$ of the solution was transferred to a $3 \mathrm{ml}$ cuvette and absorption was read at $420 \mathrm{~nm}$ and $520 \mathrm{~nm}$ wavelength using a Beckman Spectrophotometer. Colour Intensity (Cl) and Colour Taint (CT) were determined according to standard AOAC methods 2000.

Chemical Analysis: Proximate compositions of samples were determined according to AOAC (2000).

Sensory Evaluation: 15 trained panelists comprising of members of staff of the Cocoa Research Institute of Nigeria were used to assess the attributes of taste, colour, odour and overall acceptability of treated cocoa powder and beverage produced using a 9- 
point hedonic scale where 9-indicate like extremely and 1-indicating dislike extremely. Data collected were subjected to Analysis of Variance (ANOVA). Mean of data collected were separated using Duncan's Multiple Range Test.

Statistical Analysis: Microsoft SPSS for Windows 2000 was used in this study in the statistical analysis.

\section{RESULTS AND DISCUSSION}

Yeasts and fungal loads were high in cocoa powder at the warehouses. (Table 1). The proliferation of yeasts and moulds were indications that favourable conditions for the growth of moulds and yeasts were prevailing. Many reports have shown that bad storage conditions such as high temperature with high relative humidity can result in mouldy cocoa powder in the warehouse which may predispose the powder to toxic secondary metabolites such as ochratoxin A. The effect of spice powder of Aframomum danielli was evidenced in the reduction of fungal loads as well as the reduction in yeasts growth. Treating contaminated cocoa powder up to 60,000 ppm and above was highly inhibitory to contaminating fungi and yeasts. This finding was in agreement with Adegoke et al., 2000a. Other reports have shown possibilities of reduction in fungal loads and yeasts with use of essential oils, aqueous extracts and powdered extracts (Krun et al., 2001; Kim et al., 2004; Kim and Fung, 2004; Mendel et al.,
2006; Atanda et al., 2007; Kotzekidou et al., 2008; Xu et al. 2008) The monoterpene of the essential oils of A.danielli have been used against foods spoilage yeasts and mycotoxin producing moulds (Adegoke et al., 2000a).

Table 2 shows the results of the precision and recovery experiments. Recovery percentages and RSDs obtained in within- and between-day recovery experiments were similar and below $5 \%$, respectively. In addition, recovery percentages were very homogeneous at the three concentrations assayed $(\mathrm{RSD}<5 \%)$, which demonstrates the precision of the analytical procedure..

According to Table 3, OTA was present in cocoa powder sampled at different warehouses and different concentrations. OTA was present at $71.1 \%$ of all samples analyzed. Ochratoxin $-A$ varied from warehouse to warehouse. In Ibadan, seven out of nineteen samples contained OTA in the range of 0 $0.11 \mathrm{ng} / \mathrm{g}$ (2/10), $0.15-0.5$ (1/5), $0.51-1.6 \mathrm{ng} / \mathrm{g}$ (3/3) and $1.7-2.00 \mathrm{ng} / \mathrm{g}(1 / 1)$. In all, the warehouses selected for the study, it was observed that the OTA contamination in the range of $0.15-0.50 \mathrm{ng} / \mathrm{g}$ were the commonest followed by $0.51-1.6 \mathrm{ng} / \mathrm{g}$. Only four out of five samples from Lagos had greater than $2 \mathrm{ng} / \mathrm{g}$ of OTA.

Table 1: Yeasts and Fungal loads of cocoa powder treated with Aframomum danielli spice (w/w)

\begin{tabular}{lll} 
Spice treatments & Yeasts (Propagules/g) & Moulds (CFU/g) \\
Control & $8.8 \times 10^{6}$ & $9.0 \times 10^{8}$ \\
$10000 \mathrm{ppm}$ & $2.2 \times 10^{5}$ & $8.9 \times 10^{6}$ \\
$20000 \mathrm{ppm}$ & $1.6 \times 10^{3}$ & $1.5 \times 10^{5}$ \\
$30000 \mathrm{ppm}$ & $2.2 \times 10^{2}$ & $2.0 \times 10^{3}$ \\
$40000 \mathrm{ppm}$ & $1.5 \times 10^{2}$ & $3.4 \times 10^{2}$ \\
$60000 \mathrm{ppm}$ & 2 & $1.2 \times 10^{1}$ \\
$70000 \mathrm{ppm}$ & 2 & 1 \\
$80000 \mathrm{ppm}$ & - & - \\
\hline
\end{tabular}

Table 2: Within-day and between-day recovery

\begin{tabular}{lll}
\hline $\begin{array}{l}\text { OTA added } \\
(\boldsymbol{\mu} \mathbf{g k g}-\mathbf{1})\end{array}$ & $\begin{array}{l}\text { OTA measured } \\
(\boldsymbol{\mu} \mathbf{g} \mathbf{k g}-\mathbf{1})\end{array}$ & $\begin{array}{l}\text { \% Recovery } \\
(\boldsymbol{\mu} \mathbf{g k g}-\mathbf{1})\end{array}$ \\
\hline Within day & $(\mathrm{n}=3)$ & $(\mathrm{n}=3)$ \\
0.5 & 0.4 & 80 \\
5 & 3.8 & 76 \\
10 & 8.2 & 82 \\
Between-day & $(\mathrm{n}=9)$ & 72 \\
0.5 & 0.36 & 70 \\
5 & 3.5 & 79 \\
10 & 7.9 & $729)$ \\
\hline
\end{tabular}


Am. J. Food. Nutr, 2011, 1(4): 155-165

Table 3: ochratoxin A distribution in cocoa powder at some southwest Nigerian warehouse

Ochratoxin A concentration ( $\mathrm{ng} / \mathrm{g})$

\begin{tabular}{llllll} 
Warehouse & $0-0.11$ & $0.15-0.50$ & $0.51-1.6$ & $1.7-2.00$ & $>2.00$ \\
\hline Ibadan & $2(10)$ & $1(5)$ & $3(3)$ & $1(1)$ & - \\
Mushin & $6(6)$ & $6(6)$ & $5(7)$ & $3(3)$ & - \\
Ogun & $1(3)$ & $2(2)$ & - & - & - \\
Oshodi & & $1(4)$ & - & - & - \\
Ondo & $4(5)$ & $3(5)$ & $5(5)$ & - & - \\
Apapa & $2(2)$ & & $3(4)$ & - & - \\
Itire & & $4(4)$ & $2(2)$ & - & \\
Isolo & & $2(3)$ &
\end{tabular}

Table 4: Effect of $\boldsymbol{A}$. danielli powder on OTA reduction of cocoa powder

\begin{tabular}{|c|c|c|c|}
\hline $\begin{array}{l}\text { Cocoa Powder } \\
+ \\
+ \\
\text { Aframomum danielli }\end{array}$ & $\begin{array}{l}\text { OTA in samples of cocoa } \\
\text { powder } \\
(\mathrm{ng} / \mathrm{g})\end{array}$ & $\begin{array}{l}\text { OTA EU limit for cocoa } \\
\text { powder } \\
\text { ng/g }\end{array}$ & $\%$ OTA changes \\
\hline 0 & 2.63 & 2 & $24 \%$ higher \\
\hline 40000ppm & 2.5 & 2 & $20 \%$ higher \\
\hline 60000ppm & 2.22 & 2 & $9.9 \%$ higher \\
\hline 80000ppm & 1.86 & 2 & $9 \%$ lower \\
\hline
\end{tabular}

\section{Effect of $A$. danielli powder on OTA reduction of cocoa powder}

Fig 1. showed the peak of standard OTA while fig 2. showed OTA positive sample at 80000ppm A.danielli treatment. Initial OTA content of $2.63 \mathrm{ng} / \mathrm{g}$ in the stored cocoa significantly reduced to $1.86 \mathrm{ng} / \mathrm{g}$. Reduction of OTA to level less than or equal to $2 \mathrm{ng} / \mathrm{g}$ is a paramount achievement in view of the need for the safety of cocoa and cocoa products as required by the EU (table 4). Many countries have regulation for different products to protect their consumers. Treatment of contaminated cocoa powder with $A$. danielli did not only reduce OTA production but can protect the image of Nigerian cocoa powder in the international market. OTA reduction efficiency by the spice $A$. danielli might be due to the presence of oleuropin and some of its products of hydrolysis (Adegoke et al., 2000b). Other report had confirmed the reduction of Aflatoxin $B_{1}$ with O-vanillnin, chloroglucinol, pyrocatechol and oleuropine (Cowan, 1963).. A. danielli ochratoxin A reducing tendencies might not be unconnected with its antioxidant properties. Fanelli et al., (1989) have also reported that several antioxidants strongly inhibited aflatoxin production by Aspergillus parasiticus. Adegoke et al., 2000a corroborated this finding when Aframomum danielli was used in the reduction of Aflatoxin $B_{1}$ production. It therefore seemed likely that reduction in ochratoxin production in our trials, was also influenced by the antioxidative activity of the caffeic acid in the A. danielli (Adegoke et al., 2002).

\section{Sensory characteristics of $A$. danielli - treated cocoa powder}

Mean values for the multiple comparisons analysis for sensory analysis of cocoa beverage prepared from Aframomum danielli treated cocoa powder were shown in table 5

Colour: The colour attributes of cocoa beverage indicated significant differences in sample coded 745 and all other samples. Beverage 200, 835 and 921 were not significantly different in terms of colour at $p<0.05$. Sample 520 was rated lowest among all the cocoa beverage samples with regard to colour characteristics. The effect of $A$. danielli in the cocoa powder resulted in acceptable colour characteristics until $60000 \mathrm{ppm}$. Above this concentration, the colour became dull in appearance .

Taste: As for taste, a significant difference occurred between control samples and other samples into which Aframomum danielli has been added, sample 200 containing 20,000 ppm of the crude powder of $A$. danielli was rated next after the control cocoa beverage without the additive. There was no further significant difference in samples 835, 921 and 520 respectively. The preferred taste of the control cocoa beverage is not unexpected. The cocoa beverage into which $A$ danielli have been added seemed to be new to the panelists since the unfamiliar taste 
perception of $A$. danielli in cocoa beverage gave a different rating response. The addition of $A$ danielli to cocoa beverage is to create a new perception (Moscovici, 2000). Once the new cocoa beveragetreated $A$ danielli still fell in the like category, one can deduce that the attribute of $A$ danielli has been transferred to the cocoa beverage. The addition of $A$ danielli at 20,000ppm, 40,000ppm and 60,000ppm in cocoa beverage formed a new product with characteristic acceptable perception in taste. This findings was in conformity with the hypothesis of Moscovi, 2000. In fact, one of the strongest predictors of food choices is pleasant taste. . In a qualitative study by Connors et al., 2001, parely to evaluated food based on many personal values, of which good taste was very important. Good taste is also linked to the perceived quality of food (Holm and Kildewang, 1996) which decreased in the order $745>$ $200>835=921>520$. The correlation of general acceptability to other sensory parameters were shown in table 6 . There was a strong significant relationship between acceptabilities of $A$ danielli treated cocoa powder and taste, smoothness, colour and sweetness $(p<0.05)$. There is plenty of evidence of the dominating role of taste in the choice, acceptance and rejection of foods. (Connors et al.,
2001). . Correlation was significant between colour and taste $(p<0.05)$, colour and smoothness $(p<0.05)$ and colour and sweetness $(p<0.05)$. Taste also had a strong correlation to smoothness and sweetness at $\mathrm{p}<0.05$, smoothness also had a strong correlation to sweetness at $p<0.05$.

According to table 7, the effect of using Aframomum danielli as an additive in the reduction of ochratoxin $A$ is positive on the proximate composition of the cocoa powder. This is a desirable effect because the use of any additive should not change the nutritional status of the treated samples negatively. \% Protein and \% ash, \% increased with the increase in the spice powder addition. Only the fat content was not significantly affected by the addition of the spice powder. The addition of the spice powder also caused a significant increase in the \% crude fibre of the treated cocoa powder.

However, the result obtained indicated that the use of Aframomum danielli resulted in the enhancement of major minerals such as potassium, calcium, sodium and iron with increase in the concentration of the spice powder used.

Table 5.Organoleptic scores of cocoa beverage prepared from Aframomum danielli treated cocoa powder

\begin{tabular}{llllll}
\hline Sample Code & ${ }^{*}$ Colour & Taste & Smoothness & Sweetness & Overall acceptability \\
\hline 745 & $7.1 \pm 0.88 \mathrm{a}$ & $7.5 \pm 0.85 \mathrm{a}$ & $6.6 \pm 1.27 \mathrm{a}$ & $7.2 \pm 0.92 \mathrm{a}$ & $7.3 \pm 0.87 \mathrm{a}$ \\
200 & $6.3 \pm 0.95 \mathrm{ab}$ & $6.1 \pm 0.97 \mathrm{ab}$ & $5.9 \pm 2.23 \mathrm{ab}$ & $5.9 \pm 1.91 \mathrm{ab}$ & $5.4 \pm 1.24 \mathrm{~b}$ \\
835 & $6.2 \pm 1.23 \mathrm{ab}$ & $5.4 \pm 2.07 \mathrm{~b}$ & $5.4 \pm 1.65 \mathrm{ab}$ & $5.4 \pm 2.17 \mathrm{~b}$ & $5.11 \pm 2.32 \mathrm{~b}$ \\
921 & $6.0 \pm 1.25 \mathrm{ab}$ & $5.4 \pm 1.48 \mathrm{~b}$ & $4.7 \pm 1.83 \mathrm{ab}$ & $5.1 \pm 1.45 \mathrm{~b}$ & $4.78 \pm 1.39 \mathrm{~b}$ \\
520 & $5.6 \pm 1.51 \mathrm{~b}$ & $4.6 \pm 1.51 \mathrm{~b}$ & $5.3 \pm 1.34 \mathrm{~b}$ & $4.6 \pm 1.35 \mathrm{~b}$ & $4.44 \pm 1.81 \mathrm{~b}$ \\
\hline
\end{tabular}

* - \pm standard deviation)

745-0, A.danielli ; 200 - 20,000ppm A. danielli; 835-40,000ppm; 921-60000ppm; 520-80000ppm.

Table 6 : Correlation of sensory parameters of cocoa powder treated with Aframomum danielli

\begin{tabular}{|c|c|c|c|c|}
\hline & colour & Taste & Smoothness & sweetness \\
\hline Acceptability & $0.482^{* *}$ & $0.710^{* *}$ & $0.485^{\star *}$ & $0.703^{\star *}$ \\
\hline Colour & & $0.561^{* *}$ & $0.358^{*}$ & $0.389^{\star *}$ \\
\hline Taste & & & $0.466^{\star *}$ & $0.687^{* *}$ \\
\hline Smoothness & & & & $0.640^{* *}$ \\
\hline Sweetness & & & & \\
\hline
\end{tabular}

${ }^{*}$ Correlation is significant at $p<0.05,{ }^{* *}$ Correlation is significant at $p<0.01$. 
Am. J. Food. Nutr, 2011, 1(4): 155-165

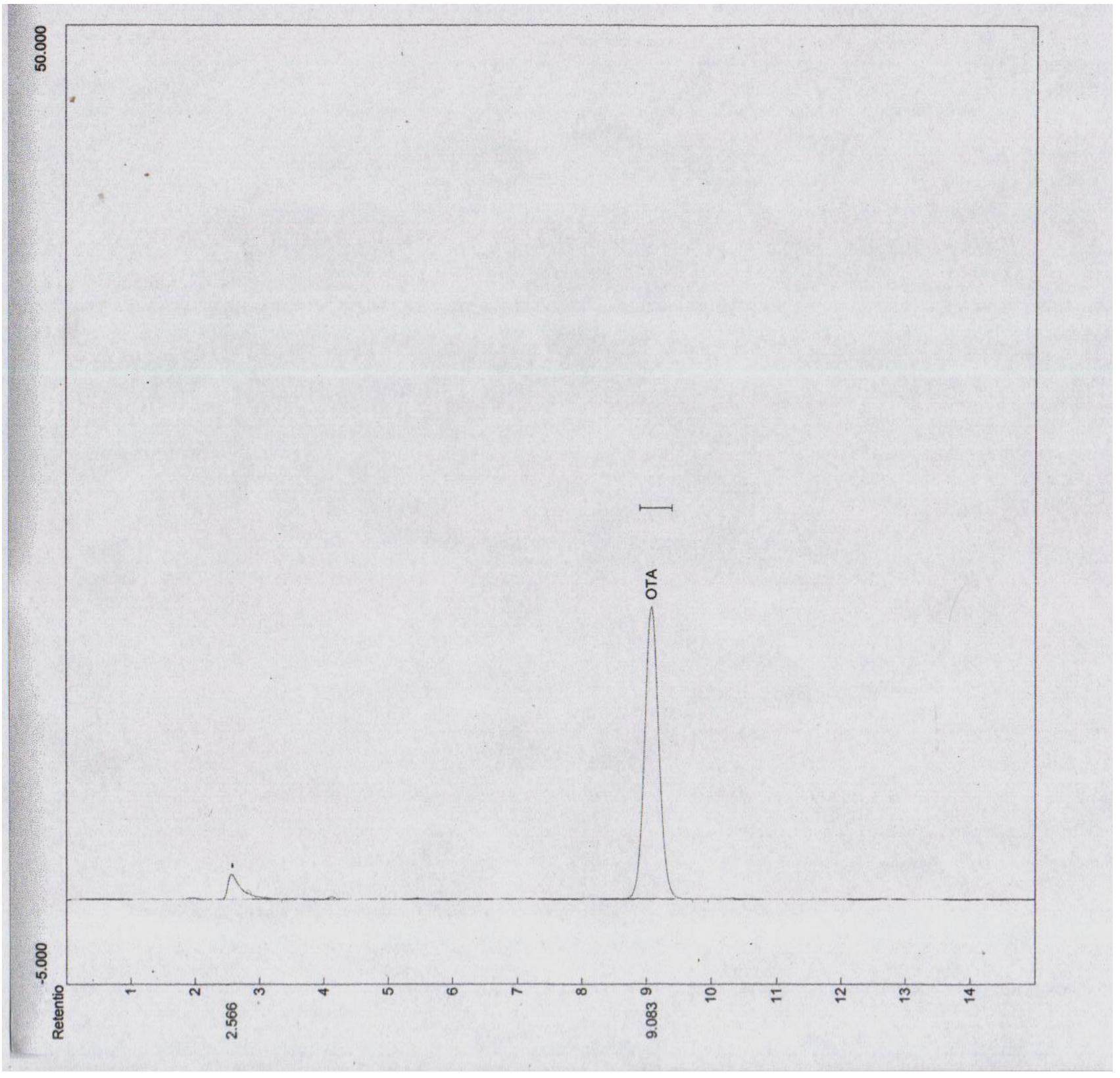

Fig. 1: HPLC chromatogram showing standard OTA with UV and fluorescent detectors 
Am. J. Food. Nutr, 2011, 1(4): 155-165

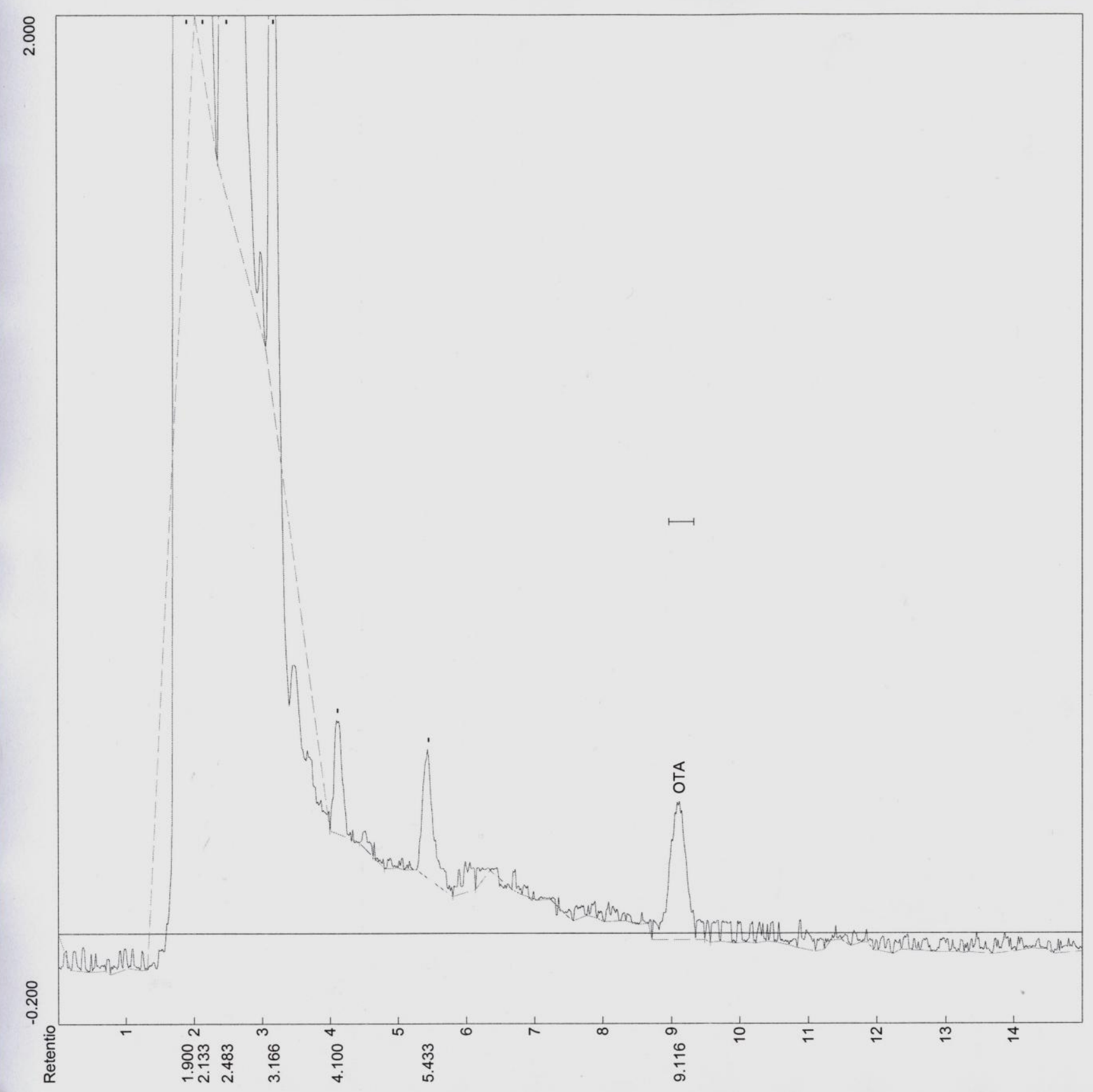

Fig. 2: HPLC chromatogram showing reduction of OTA in cocoa powder with danielli at $80000 \mathrm{ppm}$ 
Am. J. Food. Nutr, 2011, 1(4): 155-165

Table 7: Proximate composition of cocoa powder treated with Aframomum danielli

\begin{tabular}{lllll}
\hline & Control & $20000 \mathrm{ppm}$ & $40000 \mathrm{ppm}$ & $60000 \mathrm{ppm}$ \\
\hline \% protein & 20.3 & 24.21 & 25.22 & 25.67 \\
$\%$ ash & 5.5 & 6.00 & 6.68 & 7.21 \\
$\%$ moisture content & 4.2 & 4.4 & 4.6 & 4.2 \\
$\%$ fat & 10.8 & 8.33 & 8.29 & 8.53 \\
$\%$ crude fibre & 34 & 36 & 38 & 39.6 \\
Potassium $(\mathrm{mg} / \mathrm{kg})$ & $1.55 \pm 0.23$ & $1.81 \pm 0.00$ & $2.4 \pm 0.11$ & $2.66 \pm 0.00$ \\
Sodium $(\mathrm{mg} / \mathrm{kg})$ & $0.03 \pm 0.42$ & $0.08 \pm 0.23$ & $1.21 \pm 0.07$ & $1.82 \pm 0.00$ \\
Calcium $(\mathrm{mg} / \mathrm{kg})$ & $0.21 \pm 0.05$ & $0.28 \pm 0.08$ & $0.46 \pm 0.21$ & $0.88 \pm 0.11$ \\
Iron $(\mathrm{mg} / \mathrm{kg})$ & $186 \pm 0.15$ & $188 \pm 3.4$ & $200 \pm 0.33$ & $212 \pm 0.26$ \\
\hline
\end{tabular}

\pm standard deviation

Table 8:Colour characteristics of cocoa beverage prepared with A danielli-treated cocoa powder

\begin{tabular}{|c|c|c|c|c|c|}
\hline & \multicolumn{5}{|c|}{ Absorbance (nm) } \\
\hline $\begin{array}{l}\text { A. danielli } \\
\text { Concentration }\end{array}$ & & $420 \mathrm{~nm}$ & $520 \mathrm{~nm}$ & Colour Intensity & Colour Taint \\
\hline 20000ppm & $\begin{array}{l}\text { Hot } \\
\text { Cold }\end{array}$ & $\begin{array}{l}0.55 a \\
0.43 b\end{array}$ & $\begin{array}{l}1.27 a \\
1.28 a\end{array}$ & $\begin{array}{l}1.82 \\
1.71\end{array}$ & $\begin{array}{l}0.43 \\
0.34\end{array}$ \\
\hline 40000ppm & $\begin{array}{l}\text { Hot } \\
\text { Cold }\end{array}$ & $\begin{array}{l}0.63 a \\
0.43 b\end{array}$ & $\begin{array}{l}1.38 a \\
1.13 b\end{array}$ & $\begin{array}{l}2.0 \\
1.56\end{array}$ & $\begin{array}{l}0.46 \\
0.38\end{array}$ \\
\hline 60000ppm & $\begin{array}{l}\text { Hot } \\
\text { Cold }\end{array}$ & $\begin{array}{l}0.73 a \\
0.51 b\end{array}$ & $\begin{array}{l}1.44 a \\
1.23 b\end{array}$ & $\begin{array}{l}2.17 \\
1.74\end{array}$ & $\begin{array}{l}0.51 \\
0.42\end{array}$ \\
\hline $\begin{array}{l}\text { 80000ppm } \\
\text { Cocoa beverage } \\
\text { A. danielli }\end{array}$ & $\begin{array}{l}\text { Hot } \\
\text { Cold }\end{array}$ & $\begin{array}{l}0.53 a \\
0.28 b \\
0.09 b \\
0.42 a\end{array}$ & $\begin{array}{l}1.24 a \\
1.01 b \\
1.83 b \\
1.13 a\end{array}$ & $\begin{array}{l}1.77 \\
1.29 \\
0.92 \\
1.55\end{array}$ & $\begin{array}{l}0.43 \\
0.28 \\
0.11 \\
0.37\end{array}$ \\
\hline
\end{tabular}

Effect of using the spice powder of Aframomum danielli on colour production in prepared cocoa beverage was shown on table 8 . The measurement of the colour production in both the hot and cold form of the beverage becomes necessary in view of the different ways in which the cocoa beverage is consumed in all the consuming nations of the world. Since cocoa powder has a unique golden brown colouration in solution, any deviation in this colour would amount to rejection by regular consumers The spectrophotometric measurement of the colour as shown on table 8 showed that colour production of the cocoa beverage was best when hot than when cold. The increase in Aframomum danielli resulted in increase in the colour intensity as well as the colour taint of the cocoa beverage. The similarity in the colour of the Aframoum danielli is responsible for this colour compatibility. There are chemical compounds in both the cocoa powder and A.danielli responsible for the colour development.

\section{CONCLUSIONS}

From this study, the presence of ochratoxin-A in cocoa powder was detected at the warehouses at different concentrations. Suitable conditions for the growth of ochratoxin A producing moulds at the warehouse was responsible for the prevalence of ochratoxin A. The hygroscopic nature of the cocoa powder coupled with high relative humidity and high temperature at the warehouse are principal factors responsible for the measured OTA. Treatments of ochtratoxin A contaminated cocoa powder with natural spice Aframomum danielli significantly reduced OTA to a level accepted at the EU and the effect of using the spice powder was tested on proximate composition and the sensory profile of the beverage of the cocoa powder at both the hot and cold level. There was a desirable positive effect on the nutritional and the sensory values of the cocoa beverage up to $6000 \mathrm{ppm}$ and above which the organoleptic score became lower and acceptability 
also reduced. Treatment of contaminated cocoa powder should not exceed 60000ppm as any quantity above this level will make the ccocoa powder ot its beverage to have a bad taste and dull colour. Since the spice powder used in this study was crude, further works need be done to get the different fractions responsible for the ochratoxin A reduction.

\section{ACKNOWLEDGEMENT}

Authors wish to acknowledge the Executive Director, Cocoa Research Institute of Nigeria, Professor, G.O. Iremiren for his permission to publish this paper. . Dr. O.Olubawa, Director, Research is also acknowledged for useful advice.

Dr. Fademi, Director, Planning, Budgeting and Training of the Cocoa Research Institute of Nigeria is also appreciated for his moral supports. Authors wish to acknowledge the University of Szeged, Faculty of Science, Department of Microbiology for permission to use their facilities to carry out this experiment and Animal experimental stations Goddolllo, Hungary for provision of HPLC used in this study

\section{REFERENCES}

Adegoke G.O. and Skura B.J. (1994). Nutritional Profile and Antimicrobial Spectrum of the Spice Aframomum danielli K. Schum. Plant. Foods for Human Nutrition 45: 175-182.

Adegoke G.O., Iwahasi, H., Komatsu U. Obuchi K and Iwahosi U. (2000a): Inhibition of food spoilage yeasts and aflatoxingenic moulds by monoterpenes of the spice Aframomum danielli. Flavour Fragrance. Journal. 15:147-150.

Adegoke G.O., Fasoyiro S.B. and Brent Skura (2000b). Control of microbial growth, Browning and lipid oxidation by the spice Aframomum danielli. Eur. Food Res. Technol. 211: 342-345.

Adegoke G.O., Gbadamosi, Felix, E., Uzo-Peters P.I., Fallade K.O. Itiola O., Moody O. and Skura B. (2002). Protection of maize (Zea mays) and Soybeans (Glycine max) using Aframomum danielli. European . Food Research and Technology . 214: 408-411.

AOAC (2000). Official Methods of Analysis, $19^{\text {th }}$ edition. Washington D.C. Association of Analytical Chemists

Aroyeun, S.O.; Ogunbayo, J.O. and A.O. Olaiya (2006). Effect of Modified Packaging and Storage time of cocoa pods on the commercial Quality of cocoa beans. British Food Journal 108 (2): 141-151

Aroyeun S.O., Adegoke, G.O., Varga, J. Teren, J., Koscube, S., Pal, K. and Vagvolgyi, C. (2007) Effect of fermentation and storage on mycotoxigenic fungi, ochratoxin $A$ and aflatoxin B1 in cocoa beans from
Southwestern Nigeria. Malaysian Cocoa Journal 3: 3546

Aroyeun S.O.and Adegoke G.O.(2007) Reduction of ochratoxin A (OTA) in spiked cocoa powder and beverage using aqueous extracts and essential oils of Aframomum danielli. African Journal of Biotechnology 6, 5: 612-616

Aroyeun S.O., Adegoke, G.O., Varga J., Teren J., (2009a) Reduction of aflatoxin B1 and ochratoxin A in cocoa beans infected with Aspergillus via ergosterol value. World Review of Science, Technology and Sustainable Development 6, 1: 75-89

Aroyeun S.O., Adegoke, G.O., Varga J., Teren J., (2009b) Grading of fermented and dried cocoa beans using fungal contamination, ergosterol index and ochratoxin A production. Mycobiology 37, 3: 215-217

Atanda O.O., Akpan I., F. Oluwafemi (2007) The potential of some spice essential oils in the control of A.parasiticus CFR 223 and aflatoxin production. Food Control , 18 :601-607.

Bonvehi J R (2004). Occurrence of ochratoxin A in cocoa products and chocolate Journal of Agricultural and Food Chemistry,. 52: 6347-6352.

Bullerman, L.B., Lien Y. and Scier, S.A. (1977). Inhibition of growth and aflatoxin production by Cinnamon and Clove oils Cinnamic aldehyde and Engenol. Journal of Food Science, 42, 1107-1109

Connors, M., Bisogni, C.A., Sobai, J., Devine, C.M., (2001) Managing values in personal food systems. Appetite, 36: $189-200$

Cowan, M.M. (1999) Plant products as antimicrobial agents. Clinical Microbiology Review , 12 (4): 564-582

Fanelli. C. and Fabbri A.A. (1989) Relationship between lipids and aflatoxin biosynthesis. Mycopathologia 107 (2-3): $115-120$

Filltenborg, O., Frisuad, J.C., and Svendens, J.A. (1983). Sample Screening methods for molds producing intracellular mycotoxins in pure cultures. Applied and Environmental Microbiology, 45, 581-585.

Holm, L., Kildewang, H. (1996) Consumers' views on food quality, A qualitative interview study. Appetite, 27 : 1-14

IARC (1993). International Agency for Research on Cancer. IARC monographs on the Evaluation of Carcinogenic Risk to Humans, Vol. 56, IARC Working Group, World Health Organization, Cyon, France, pp. 489-521.

Kim, S., Ruengwilysup, C., and Fung D.V.C. (2004) Antibacterial effect of water-soluble tea extracts on food borne pathogens in laboratory medium and in a food model. Journal of Food Protection 67, 2: 26082612 
Kim, S., and Fung D.V.C. (2004) Antibacterial effect of water soluble arrow root (Puerariae radix) tea extracts on food borne pathogens in ground beef and mushroom soup. Journal of Food Protection 67, 9: 1953-1956

Klich, M.A. and Pitt J.I., (1988). A Laboratory Guide to common Aspergillus Species and their Telemorphs (Sydney: CSIRO, division of Food Processing).

Kotzekidou, P., Giannakids, P., Boulamatsis, A., (2008) Antimicrobial activity of some plant extracts and essential oils against food borne pathogens in vitro and on the fate of inoculated pathogens in chocolate. LWT 41: 119-127

Krun, Y.K., Michael, D.P., Hee, J.C., (2001) Antibacterial activity in extracts of Camellia japonica L. petals and its application to a model food system. Journal of Food Protection 64, 8: 1258-1260

Lamper, C.S., Teren, J., Bartok, T., Komoroczy, R., Mesterhazy, A., and Sagi, F., (2000) Predicting DON contamination in Fusarium-infected wheat grains via determination of the ergosterol content. Cereal Research Communication 28, 3: 337-344

Li-Lian, J., Yu-Ming, L., Gui-Long yan (2008) Studies on the antimicrobial activities of extracts from Eupatorium lindleyanum DC against food spoilage and food-borne pathogens. Food Control 19: 905-1001

Mendel, F., Philip, R.H., Carol, K.L., Robert, K.M,, and K., (2006) Antimicrobial of tea Catechins, theaflavins and tea extracts against Bacillus cereus. Journal of Food Protection 69 (2) : 354-361
Moscovici, S., (2000) Social representations. Exploration in social psychology, Cambridge Polity 4 (6) : 33-50

Neda M., Bilijana B., Marina S. and Natas S. (2004). Antimicrobial and Antioxidant activities of Melissa officinalis L. Essential oil. J. Agric. Food Chem. 52: 2485-2489.

Ogunbanwo (2005). Incidence of Mycotoxins in local and processed foods marketed in Nigeria. In a paper presented at a workshop on Mycotoxins in food and agricultural products, Lagos, Nigeria

Pitt, J.L. and Hocking, A.D., (1997) Fungi and Food Spoilage Academic Press, New York

Soliman KM, Badeaa RI (2002). Effect of oil extracted from some medical plants on different mycotoxigenic fungi; Food Chem. Toxicol. 4: 1669-1675.

Tafuri A., Ferracane R., A. Ritieni (2004) Ochratoxin-A in Italian marketed cocoa products Food Chemistry 88: 487-494

Teren J., Varga J., Hamari Z., Rinyu E. and Kevei, F. (1996). Immunochemical detection of Ochratoxin A in Black Aspergillus Strains. Mycopathologia 134: 171176.

Wagner-Merner, D.T. (1977). Arenicolous fungi from the South and Central gulf coast of Florida. Nova Hedwigia 23: 915-922.

Xu, Y.,Hall., Wolf-Hall, C., (2008) Antifungal activity stability of flaxseed protein extract using response surface methodology Journal of Food Science 73, 1: 9-14 